\title{
ARSLAN, Meryem (2019). Muhammed bin Mustafa El- Gûrânî Kitāb-ı Tercüme-i Težkire-i Dāvūd Fi 'ilmi'ț-Tıbb (Metin-Tematik Dizin-Sözlük), Ankara: Türk Dil Kurumu Yayınları, 1148 s.
}

\author{
Songül ERDOĞAN*
}

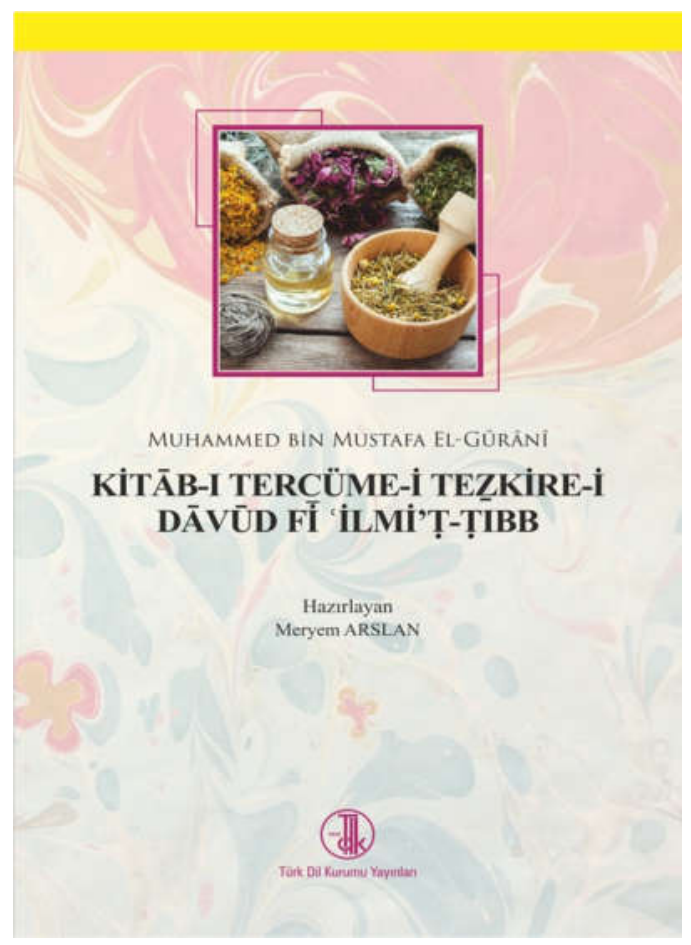

Sağlık ve sağlıkla ilgili uygulamalar insanlık için oldukça önemli bir alandır. İnsanoğlunun çeşitli sağlık problemleri karşısındaki çare arayışları geleneksel tıbbın doğmasına zemin hazırlamıştır. Geleneksel tıptaki bazı uygulamalar ise zamanla modern tıbbin alt yapisinı oluşturmuştur. İster geleneksel ister modern yöntemlerle olsun insanoğlunun şifa bulma amacıyla yapmış oldukları çalışmalar beraberinde bir tıp terminolojisini de doğurmuştur.

Tarihî tıp metinleri konusunda yakın zamanda yapılan çalışmalardan birisi Meryem Arslan'a aittir. Çalışma 2019 yılında Türk Dil Kurumu yayınları arasından çıkmıştır. Toplam 1148 sayfadan oluşmaktadır. Kitabı̀n dış kapağında mavi, pembe ve beyaz renklerin ağırlıkta olduğu bir ebru deseni ve üst orta kısımda tedavi amaciyla kullanılan çeşitli bitkilerin yer aldığı küçük bir fotoğraf yer almaktadır.

Çalışmanın konusu 17. yüzyılda Muhammed bin Mustafa El-Gûrânî tarafından Osmanlı Türkçesine çevirisi yapılan Kitāb-ı Tercüme-i Težkire-i Dāviud fi 'İlmi'țTıbb'adlı eserdir. Tarihî bir tıp metni olan eser, Dâvûd-1 Antâkî'nin kısaca Tezkire-i Dâvûd olarak bilinen Tezkiretü Uli'l-Elbāb ve'l-Cāmi ü li'l- 'Acebi'l'Ucāb isimli Arapça eserinin 3. babının 17. yüzyılda Türkçeye yapılmış çevirisidir. Çalışmanın konusu olan eser, Süleymaniye Kütüphanesi'nde "Hekimoğlu Ali Paşa Koleksiyonu, Tıp, 1052, Nesih, Demirbaş No.: 566, 366 v." olarak kayıtlıdır. Tespit edilebilen tek nüsha olması sebebiyle çalışma bu kayıttaki eser üzerinden yapılmıştır.

Arslan, çalışmasında "Bölüm I, Bölüm II, Bölüm III” olmak üzere üç ana bölüme yer vermiştir. "Bölüm I” çalışmanın “Giriş" bölümünü oluşturmaktadır (s.13-50). Giriş bölümünde beş alt başlık yer almaktadır. Bunlar: Çalışmanın Konusu,

* Dr. Öğr. Üyesi, Kırşehir Ahi Evran Üniversitesi, Fen-Edebiyat Fakültesi, Türk Dili ve Edebiyatı Bölümü, songultanboga@gmail.com, ORCID: 0000-0002-5355-9399 
Amacı, Malzemesi, Nüsha Betimlemesi ve Çalışmanın Yöntemi”dir. Çalışmanın konusu ve amacı hakkında genel bir bilgi verildikten sonra, çalışmanın malzemesi bölümüne geçilmiştir. Burada eserin müellifi, Dâvûd-1 Antâkî'nin hayatı ve eserleri kapsamlı bir şekilde açıklanmıştır. Yazarın verdiği eserlerden yola çıkılarak müellifin İslam tıp tarihindeki yeri açıklanmaya çalışılmıştır. Arslan, Antâkî'nin eserleri ve bulundukları kütüphaneler hakkında bilgi vermiş, çeşitli kaynaklardan yararlanarak eserlerin bulunduğu kütüphaneleri de tablo ile göstermiştir. Kör ve kötürüm olmasına rağmen matematik, felsefe, astroloji, psikoloji alanında da eserler veren Antâkî'nin aynı zamanda iyi bir şair olması da dikkat çekicidir. Birçok alanda sayısız eser bırakan, dâhilik derecesinde güçlü bir hafızaya sahip olan Dâvûd-1 Antâkî hakkında yeterince çalışma yapılmamış olması Arslan'ı çalışma konusu hakkında daha çok yüreklendirmiştir. Eserin müellifi Antâkî ve eserleri hakkında yeterince bilgi verildikten sonra eserin müstensihi Muhammed bin Mustafa El-Gûrânî'nin hayatı ve eserlerine de yer verilmiştir. Müellifin çalışmanın konusunu oluşturan Kitāb-ı Tercüme-i Težkire-i Dāvūd fi 'İlmi'ț-Ṭıbb adlı eserin tanıtımına genişçe yer verilmiştir. Kitabın Arapça müellif ve müstensih nüshalarından alınmış görüntülerle okuyucu, çalışılan eser hakkında aydınlatılmıştır. Dördüncü kısım olan nüsha betimlemesinde ise üzerinde çalışılan nüsha sayfa sayısı, satır sayısı, yazı özellikleri gibi çeşitli yönlerden değerlendirilmiştir. Giriş bölümünün son kısmı olan beşinci alt bölümde çalışmanın yöntemi ortaya konmuştur. Bu bağlamda 17. yüzyılın tıp anlayışı, metin kurulurken uyulan esaslar da belirtilmiştir.

Araştırmacının "İnceleme" adını verdiği "Bölüm II", "Metnin Noktalama İşaretlerine Göre Düzenlenmiş Çeviri Yazısı", "Tematik Dizin”, "Eserde Arapça Alfabetik Sırayla Verilen Illaç ve Illaç Ham Maddeleri” olarak üç alt bölümden oluşmaktadır. İlk olarak metnin noktalama işaretlerine göre düzenlenmiş çeviri yazısına yer verilmiştir. (s.51-617) Eser okuması "[2a]" sayfa numarası ile başlamıştır. Sayfa numaraları köşeli parantez ve koyu renk ile gösterilmiştir. Eser okunurken metindeki harekelere sadık kalınmış, okumada herhangi bir imla birliğine gidilmemiştir. Okunuşundan emin olunmayan kelimeler parantez içerisinde soru işareti konularak gösterilmiştir. Metinde geçen derkenarlar, ilgili kelimeye dipnot verilerek açıklanmıştır. Metinde geçen ve çeşitli sebeplerden dolayı okunamayan kelimeler de tahminî okumalarla tamamlanmıştır. Bu tahminî okumalar da parantez içine soru işareti konularak gösterilmiştir. Çeviri yazı metinde italik, koyu ve altı çizili kelimeler olduğu görülecektir. Burada el yazma nüshaya sadık kalınmıştır. El yazması nüshada kırmızı mürekkeple yazılan (ve) şerbeti, (ve)bedeli, ve a lem gibi ifadeler, italik ve koyu olarak; ilaç ham maddeleri koyu, italik ve altı çizili olarak gösterilmiştir. İlaç ham maddeleri, ayrıca kolay fark edilmesi için aslına uygun olarak alt satıra taşınmıştır.

"[2a]" sayfa numarası ile başlayan metin çevirisi "[364a]" sayfası ile sona ermiştir. Metin çevirisinin [2b] sayfasından itibaren alfabetik olarak tıpta kullanılan bitkiler, madenler ve diğer unsurlara yer verilmiştir. Metinde geçen 
madde başı olan ilk tıp terimi "Alūsen" dir. Metinde anlamı ile birlikte şu şekilde yer alır:

“Alūsen: Yunan'dır. Ricli'l-ġurāb dahı dirler. Ve Mișır ehli cezerü'ş şeyțān dirler. Ve Şām ehli haşş̧̧̈̈'s-süluhfāt dirler. 'Arabca mübriyü'l keleb dirler. Ve ol, bir ottur ki budağ̀ rāziyāne gibi bir arşūn uzanur ve yaprakları kızıl ile siyāh mābeynindedir ve tohumı nān-h̆̄āh gibidir. Kesici ve rāyihası šakildir. Eger vahşsizik ile ki bir otuñ adıdır, harf-i vāvda żikr olınsa gerek. Karışdırsalar fark olınmaz. Ve ol otı huzeyrān ayında cem' derler imiş. Tabi'atı hărdır üçünci derecede evvelki derecesinde ve huşkdır dördincide. Ve bir kavlde dimişler: "Hārdır ikincide ve huşkdır evvelkide." Bal ile yaralar ěserlerine yā kel olan başa yā çıbanlara sürseler zāyil ider. Ve eger buruna țamzırsalar zükāmı kaț ider. Ve eger bal ile içseler diki'n-nefesi ve balgame'l-kașabayı kuluncr ve h̆ām mi deyi kaț'eyler ve bögrekleri șāfi ider. Mi dede olan fażalātı çıkarur, hażm-ı ța 'ām ider ve galiz olan yelleri ihrāc eyler. Bir kavlde dimiş ki: "Eger kuzıl hırka ile başda așșalar baş àgrısın zāyil ider." Cigere żararı var. Ve ketire aniñ muṣlihidir. Ve şerbeti: İki dirhem. Ve bedeli: Haşişetü'l fārl yā habbü'l-ḡārl nıșfi kadarınca veyā iki mišli nān-h̆ ${ }^{v} \bar{h}$ "'(s.53).

Son madde başı ise "Yenmūye" maddesi olup metinde şu şekliyle kayıtlıdır:

"Yenmūye: Hindibānıñ bir nev idir veyā bir Maǵribi otdır ki șaru çiçekleri olur ol yaraları etlendirir." (s.617).

Satır sayısı değişkenlik gösteren eserde metin bölümünün geniş yer tutması ayrıca Arapça, Farsça ve Yunanca gibi dillerden alınmış söz varlığının bulunması, tamlamalardan sıkça faydalanılması Arslan'ın bu konuda oldukça dikkatli bir tutum sergilediğini göstermektedir.

"Tematik Dizin" (s.618-990) başlığını taşıyan ikinci alt bölümde "Dizin Hazırlarken Uyulan Esaslar" ve "Tipla Illgili Sözleri İçeren İsimler ve Fiiller Dizini" başlıkları yer almaktadır. Dizin Hazırlanırken Uyulan Esaslar alt başlığında, tematik dizinlerin hazırlama yöntemleri açıklanmıştır. (s.618-624) Tematik dizin yönteminin seçiminde, metnin hacimli olması ve tıp terimlerinin ortaya çıkarılması fikri etkili olmuştur. "Tıpla İlgili Sözleri Iç̧eren Ísimler ve Fiiller Dizini" çalışmanın dizin kısmını oluşturmaktadır (s.625-990). Bu bölümde eserde geçen ve tıbbi terim olarak kullanılan isimlere ve fiillere alfabetik olarak yer verilmiştir. Basit, türemiş isimlerle birleşik yapıdaki fiilleri bu dizinde görmek mümkündür. Fiiller verilirken -mAk fiilimsi ekine yer verilmeden fiilin sonuna “" işareti konularak fiilin açıklamasına yer verilmiştir. Dizindeki madde başları açıklanırken eserde geçen anlam dikkate alınmış, sözcügün bu anlamı ile geçtiği sayfa ve satır numarasına yer verilmiştir. Dizin kısmında mütercimin imla tercihlerine sadık kalınarak aynı anlama gelen farklı yazılışları bulunan sözcükler için farklı madde başları yapılmış ve bunlar sayıca en çok hangisi kullanılmışsa ona gönderme yapılmıştır. Tematik olarak hazırlanan dizinde eş ve yakın anlamlı sözcükler karşılaştırılarak verilmiştir. Örneğin: “yılan: Yılan. (krş. aşkari, ılan, 
hayye, hırş̧ā, kııșa, mersā, rakş, sāliḥ, șamā, sānḥa, șıll, tenin)” şeklinde verilerek okuyucunun benzer anlamları bir arada görmesi sağlanmıştır. (s.973) Metinde geçen bitki isimlerinin Türkçe karş1lıklarından sonra parantez içerisinde, italik olarak, bitkilerin bulunabilen Latince karşılıklarına da yer verilmiştir.

İnceleme bölümünün üçüncü alt başlı̆ğ "Eserde Arapça Alfabetik Sirayla Verilen Illaç ve İlaç Ham Maddeleri"dir. (s.991-1089) Bu bölümde metinde geçen Arapça alfabetik sırayla verilmiş ve kırmızı mürekkeple belirgin hâle getirilmiş ilaç isimleri, ilaç ham maddeleri, bunların eş anlamlıları ve mizaç özellikleri, ayrıca Dâvûd-1 Antâkî'nin 155 madde başıyla ilgili olarak yaptığı etimolojik açıklamalar ile kelimelerin dizinde hangi başlıkta geçtiğinin açıklaması tablo ile gösterilmiştir. Bu tabloda eserde geçen 2015 tane ilaç ismi ve ham madde adına yer verilmiştir.

Eserin “Bölüm III” başlığını taşıyan son bölümü "Sonuç ve Öneriler” kısmıdır (s.1091-1096). Yazar bu bölümde çalışmanın genel bir değerlendirmesini yaptıktan sonra eserin özellikle tıp tarihi ve Türk dili açısından önemini vurgular.

Çalışmanın "Ek" kısmı da oldukça geniş hazırlanmıştır. Bu bölümde tematik dizin listelerine yer verilmiştir. Bu liste temalarına göre şu alt başlıklara ayrılmıştır: Bitki Ísimleri ve Bitki İsimleri ile İlgili Kelimeler Dizini Listesi (s.1097-1112), Hayvan İsimleri, ve Hayvan Ísimleri ile İlgili Kelimeler Dizini (s.1113-1114), Maden İsimleri ve Maden Ísimleri ile Ilgili Kelimeler Dizini (s.1115-1116) Yiyecek ve Içecek ile İlgili Kelimeler Dizini (s.1117-1118) Toprak ve Toprakla Illgili Kelimeler Dizini (s.1119) Birinci Dereceden Tipla İlgili İsimler Dizinleri, Öncesi ve Sonrası Süreçleriyle Hastalık, Rahatsızlık ile Illgili Kelimeler Dizini (s.1120-1125) Organ, Doku, Salgl ve Vücut Sistemleri ile Illgili Kelimeler Dizini (s.1126-1127) Ilaçlar, İlaç Hazırlama ve Kullanım Şekilleri ile İlgili Kelimeler Dizini (s.1128-1131), Tip Eserleri Dizini (s.1132), Yer İsimleri Dizini (s.1132), Arapça İbareler Dizini (s.1133), Tıbbi Fiiller Dizini (s.1134-1139). Son olarak çalışmada yararlanılan kaynaklara "Kaynaklar" başlığı altında yer verilmiştir (s.1140).

Arslan, oldukça hacimli bir eser olan "Kitāb-ı Tercüme-i Tezkkire-i Dāvūd fi 'İlmi't-Ṭbb" adlı yazmayı transkribe ederek üzerine kapsamlı bir tematik sözlük hazırlamıştır. Hazırlamış olduğu bu tematik sözlükle özellikle 17. yüzyılda kullanılan tıp terimlerini ortaya çıkararak Türk dilinin 17. yüzyıldaki söz varlığı hakkında çalışma yapan araştırmacılara 1şık tutmaktadır. Çalışmanın kapsamı dışında olması sebebiyle eser üzerinde gramer incelemesi yapılmamıştır. Eserin metin kısmı incelendiğinde gramer açısından da zengin olduğu görülmektedir. Ayrıca çalışma sadece dil açısından değil dönemin halk sağlığı ve tıp anlayışı ile ilgili uygulamalarına yer verdiği için tıp açısından da oldukça önemlidir. $\mathrm{Bu}$ yönüyle Arslan'ın çalışması disiplinler arası bir çalışma özelliği de taşımaktadır.

Türk diline ve Türk halk bilimine yapmış olduğu katkıdan dolayı Arslan'a teşekkür eder, yeni çalışmalarında başarılar dileriz. 